DOI 10.15826/qr.2019.3.404

УДК 030(470)+321.64+351.751+070.3

\title{
KNOWLEDGE IS POWER: THE STORY OF THE GREAT SOVIET ENCYCLOPAEDIA*
}

\author{
Irena Vladimirsky \\ Achva Academic College, \\ Beer Tuvia, Israel
}

This article focuses on the history of national encyclopaedia publishing in Soviet Russia, which was similar to the national encyclopaedias of France, Great Britain, the US, and the pre-revolutionary Russian Brockhauz - Efron Encyclopaedic Dictionary. The Soviet enterprise was an attempt to create an encyclopaedia combining universal knowledge and ideological values. Every revolution starts with a new understanding of reality and public access to a certain type of knowledge, for which encyclopaedias are emblems. The history of encyclopaedia publishing in Soviet Russia demonstrates how difficult and even dangerous encyclopaedias are in times of social transition and political strife. Encyclopaedias were claimed to reshape their users' mentality and change their habits: they represented a newly established social order based on a monopoly over knowledge and power. Two editions of the Great Soviet Encyclopaedia are used to illustrate the transition from new, revolutionary, and sometimes even provocative content to an entirely institutionalised enterprise with a measured dose of truth, strict censorship, and a system of checking and double-checking. The total financial dependence of encyclopaedia publishers, editors, and contributors on the state turned the encyclopaedia into an additional tool in the communist education of Soviet citizens.

Keywords: Soviet encyclopaedias; knowledge and power; totalitarianism; censorship in the Soviet Union; institutionalisation of knowledge; readership in the Soviet Union; State Publishing House.

Рассмотрена история создания национальной энциклопедии в Советской России, подобной национальным энциклопедиям Великобритании, Франции, Германии, США и дореволюционного российского издания Брокгауза и Эфрона. Новая советская энциклопедия изначально планировалась как издание, сочетающее идеологические установки своего времени с универсальными интеллектуальными ценностями. Каждая революция начинает свой путь с осмысления созданных ею новых реалий и системы образования, публичным выражением которых и является национальная энци-

${ }^{* 1}$ Citation: Vladimirsky, I. (2019). Knowledge is Power: The Story of the Great Soviet Encyclopaedia. In Quaestio Rossica. Vol. 7, № 3. P. 736-750. DOI 10.15826/qr.2019.3.404.

Цитирование: Vladimirsky I. Knowledge is Power : The Story of the Great Soviet Encyclopaedia // Quaestio Rossica. Vol. 7. 2019. № 3. P. 736-750. DOI 10.15826/qr.2019.3.404.

(C) Vladimirsky I., 2019

Quaestio Rossica • Vol. 7 • 2019 • № 3, p. 736-750 
клопедия. История советской энциклопедии наглядно демонстрирует, насколько сложен и опасен путь ее создания, особенно если он начинается с эпохи глобальных общественных и политических коллизий. Энциклопедия задумывалась как издание, способное выработать новый тип мышления, сформировать культуру самообразования у своих читателей, направленную на понимание концепции «знание - сила». Период между первым и вторым изданием Большой Советской энциклопедии демонстрирует переход от нового, неординарного и даже провокативного содержания к четкой институализированной структуре со строго дозированной долей правды, внутренней цензурой, узаконенными правилами написания статей и системой многоуровневого рецензирования. Финансирование энциклопедии, зарплаты редакторов и авторов статей также регламентировались государственными установками, одной из которых была пропаганда почти в каждой статье коммунистического образа жизни и мышления.

Ключевые слова: советские энциклопедии; наука и власть; тоталитаризм; цензура; институализация системы знания; политика самообразования; Государственное издательство.

Encyclopaedias play the roles of important social agents which document moments of social and cultural as well as political transition. The Bolshevik revolution of 1917 created a new vision of reality associated with the released activity of the toiling masses and the need to produce a new conception of knowledge, a new constellation of power, and a new vision of the self and the other. Bolshevik ideology pretended to be global and universal, so it is not surprising that the encyclopaedia genre was chosen in order to establish a new source of truth and authoritative information for citizens in Russia and abroad.

Almost immediately after the revolution, the new Bolshevik authorities decided to reconstruct intellectual life and form a new academic elite according to revolutionary ideological patterns. In the eyes of the regime, the birth of a national encyclopaedia symbolized maturity, seriousness, the progress of intellectual life, academic activity, and the readiness of academicians to contribute to civil society's universal bank of knowledge [От редакции, 1926]. After a period of reconstitution which included a bloody civil war (1918-1920) and different economic experiments (war communism of 1918-1920 and the beginning of the New Economic Policy in 1921), the time came to rearrange intellectual life in Russia, along with its academic and educational institutions, on a new ideological basis. The People's Commissariat for Education (Narkompros) was responsible for a whole system of formal and informal education, as well as the development of science, literature, arts, music, museums, and theatres: this was directed by the strong hand of true political ideology. The first state of the proletariat searched for new kinds of educational activity that would establish a revolution in human knowledge similar to the changes in the existing social hierarchy. The development of creative thinking and new ed- 
ucational programmes in physics, mathematics, and chemistry were especially welcomed. These were based on group activity according the subjects' principles, with teachers or professors serving as mentors. Great numbers of Schools of the Working Youth were established in order to promote the study of industrial technology, agriculture, medicine, zoology, and pedagogy by representatives of the working class. From 1924, institutions of higher education accepted new students mostly on the class principle; representatives of the bourgeois classes were limited to 20 percent of all students. 75 percent of the newly accepted proletarian and peasant students were very poor, and so were provided with state stipends and accommodation. At the same time, the Bolsheviks felt the lack of qualified institute and university staff, so several state decrees were adopted in order to improve the working and living conditions of prominent scientists and professors. In 1921, a special degree was adopted: "On establishing favourable working conditions for the academician Ivan Pavlov", the only Nobel Prize laureate of Bolshevik Russia [Декреты Советской власти, т. 12, с. 313]. From 1926, Narkompros was the only body responsible for the activity of the Russian Academy of Sciences, universities, and other institutions of higher education. Under the auspices of the Council of the People's Commissars, the Department of Science Development and Regulation was responsible for the activity and practical achievements of scientific institutions within the Academy of Sciences, the People's Commissariat of Agriculture, and the Supreme Soviet of the National Economy (VSNKH - Vysshii Sovet Narodnogo Khozyaistva).

Book and encyclopaedia publishing were not among the highest priorities of the new Bolshevik regime, so its turn came only in 1924. Up to 1924, the Soviet government accumulated the necessary resources for publishing activity. In 1918, a technical soviet on publishing house management was established. Its duty was to register all private publishing houses and their property and to control their activity. Most private publishing houses, including the one most famous for its high-quality dictionaries and encyclopaedias, Brockhaus - Efron, were subjected to nationalization. It was strictly forbidden to buy and sell printing equipment or move printing and binding equipment and typographic fonts within the Russian Federation without the special permission of the printing department of the VSNKh. All 1,573 registered publishing houses in the Russian Federation were nationalized by 1922 [Симзен, с. 211-214].

The initiative to institutionalize the Soviet encyclopaedia business was strongly advocated by Miron Vol'fson (1870-1932), a prominent personality of the State Publishing House (GIZ - Gosudarstvennoe Izdatel'stvo) and one of the few people with experience in encyclopaedia publishing from pre-revolutionary times. He saw encyclopaedia publishing as an important means to influence and educate the vast masses of the population and to satisfy the demands of Soviet Marxist doctrine. He found support from the prominent scientist and party member Otto Schmidt (1891-1956), who ran the GIZ in 1921-1924. In such a traditional and religious country as Russia, the new proletarian encyclopaedia had to outdo the Bible as the 
one authoritative guide to daily life [Kassof, p. 55-57; Steila, p. 100-102]. In earlier printed dictionaries and encyclopaedias, different and sometimes contradictory opinions co-existed peacefully. The new Soviet encyclopaedia had to define a uniform worldview based on dialectical materialism [Вольфсон, с. 3-4]. In 1924 by the Decree of the Central Executive Committee of the USSR, a cooperative publishing house called 'Soviet Encyclopaedia' (Sovetskaia Entsiklopediia) was organized under the auspices of the GIZ. The Soviet bureaucrats who ran the Soviet Encyclopaedia publishing house thought that publishing the encyclopaedia would be as easy as taking over the Winter Palace, and planned that the first complete edition of the Great Soviet Encyclopaedia (in 25 volumes) would be finished within three years, 1924-1927. However, this original plan could not be fulfilled without intensive preliminary work. First of all, it was necessary to find an appropriate building for the encyclopaedia staff and publishing equipment. Then, it was necessary to define the encyclopaedia's structure, the structure of its departments and sub-departments, and the list of contributors. In addition, every new appointment had to be approved by several Soviet committees.

The creation of ideological encyclopaedias as an important educational tool became one of the more complicated tasks of the new Soviet regime. The Great October Revolution and the strengthening of Soviet power established the necessary political conditions for the proletariat as a new ruling class to be able to approach universal knowledge as concentrated in encyclopaedias [Энциклопедии советские, с. 498-502]. The process of building the socialist project and the involvement of the toiling masses in political and economic life resulted in increasing demand for encyclopaedias. Soviet encyclopaedias became an easily available and concentrated essence of the knowledge created, adopted, and recommended by the state. The proletariat needed encyclopaedic knowledge in order to reconstruct the state machine, rehabilitate an economy destroyed by WWI and the Civil War, study and employ new technology, create the new Red Army, and establish a new system of education. According to the Bolsheviks, prerevolutionary encyclopaedias were the intellectual product of bourgeois society and reflected an anti-proletarian and anti-revolutionary ideology unacceptable in a socialist society.

The first volume of the first edition of the Great Soviet Encyclopaedia (GSE) was released only in 1926, while its last volume was published in 1947. The general work on the Soviet encyclopaedia was coordinated by the presidium of the GSE, which consisted of party and soviet authorities. The main GSE editorial board was responsible for connecting and communicating with Soviet higher educational and research institutions and coordinating its editorial sections. The list of departments, subdepartments, and their members was printed within every GSE volume, the frequently changing names showing how easily one could find favour or disgrace in the eyes of the new regime. The list of department and subdepartment editors within the first volume can be used as an illustration of the great Stalinist purges of 1937-1938: ten out of twelve department 
editors were repressed or died. Finding the proper match between academic research and the political attitude of encyclopaedia editors and contributors was a difficult mission, especially for the natural and technical sciences. Among the editors and contributors of the first volumes of the GSE were the names of many scientists and researchers who had begun their professional and academic career long before the Bolshevik revolution. Nevertheless, a minimum of Bolshevik political orientation was essential even for ordinary encyclopaedia contributors [РГАСПИ. Ф. 17. Оп. 163. Д. 546. Л. 60]. The encyclopaedia's scientific departments consisted of the natural and theoretical sciences; the technical and applied sciences; the technique and agricultural sciences; economics; the scientific organization of labour; history and law; philosophy, logic and dialectical materialism; pedagogy and people's education; literature, art, and linguistics; and the military sciences [Редакторы отделов]. The departments' names show an innovative approach to different social and economic problems, an attempt to find a scientifically-explained foundation to quick changes in reality, and a strong belief in revolutionary energy. Membership of the Communist Party was mandatory for department and sub-department editors. Some of them even performed party and soviet duties.

For the encyclopaedia's editorial board, it was very difficult to define the degree to which revolutionary thinking should influence the natural sciences. The only possible solution was to declare that new discoveries in technology and physics were closely connected with the creative energy of the toiling masses freed by the revolution. In the social sciences, dialectical materialism became the only accepted doctrine: the theoretical and applied sciences had to use the Marxist dialectical method in their research as well. At the same time, however, political voices distinct from Marxist theory were also represented. The first edition of the GSE was to be clearly written and understood by workers, peasants, intelligentsia, party and soviet administrators, students, peoples, and even housewives [От редакции, 1926]. Soviet and party workers should find within its pages reference material which they could use as guidelines in their everyday work. Entries including information of a purely professional character and defined as relevant for a limited number of encyclopaedia readers was to be printed in smaller characters.

The editors promised to publish 30 encyclopaedia volumes within six years: each volume was to consist of 25-27 printing sheets with two columns on every page, 8-10 colourful geographical maps, and 20 illustration plates. Additional visual material such as tables, technical illustrations, diagrams, and sketches were included within the text of the relevant entry. The encyclopaedia did not plan to make any commercial profit; it was purely a state enterprise. After the publishing of the first five volumes, it was evident that the general number of volumes would be greater than expected. Editors did not put a length limit on encyclopaedia entries: indeed, such was hardly possible, especially if the entry was written by distinguished soviet or party authorities. Very often, new entries were included without preliminary arrangement or were recommended by party and soviet bodies on the spot. 
By 1929, the number of planned volumes grew to fifty. There were 80,000 private and collective subscribers. The organization of the subscription was arranged by $G I Z$, and it was mandatory for all state, soviet, and cultural organizations (libraries, institutions of higher education, central and local administrations, etc.). Subscribers sent letters to the encyclopaedia editing board, complaining that the GSE publishing house was releasing only four volumes annually and that it would take ten more years to publish the complete set. Not all the volumes were published in alphabetical order, since they were released as soon as they were ready for print: volume ten was published after volume twelve and volume eleven was published at the end of 1930. The subscription price was relatively high even for collective subscribers. Individual subscription was opened for German and American citizens and organizations [Осинский, с. 1]. A special commission of the Workers' Inspectorate (Rabkrin) was appointed to check all subscriber complaints, but it decided to support the further publishing of this first Marxist encyclopaedia as an important enterprise for the world's first socialist state.

Encyclopaedia contributors were obliged to include Russian-language sources together with a bibliography of entries in foreign languages and a Russian translation of the main works of foreign writers and poets: these had to be accurate with regards to the original names of works and the place and year of their publication. Encyclopaedia contributors who themselves were the subjects of entries were always asked to check the entry devoted to them and make corrections if necessary. The usual payment to a contributor was 240 rubles for one printed sheet, which was a considerable sum of money at that time [РГБ. Отд. рукописей (Архив А. Горенфельда). Ф. 221. Д. 358. Л. 2]. After the monetary reform of 1924, the monthly salary of a qualified worker was about 40 rubles, while state clerks got about 100 rubles and qualified specialists were paid about 165 rubles [Барсенков, Вдовин, с. 345-347].

Special critical attention was paid to the history and law sections. Marxist historians were asked to place more focus on modern revolutionary movements and the history of socialism in Europe and Asia. The idea of the permanent revolution was still popular, so the number of entries on ancient and medieval history was considerably reduced in favour of general theoretical entries on the universality of the Bolshevik revolutionary experience in social and economic issues [Зайдель, с. 239-244]. The use of the encyclopaedia as a substitute for university and institutional text-books was so great that it was decided to strengthen the encyclopaedia's publishing committee with Grigorii Broido, rector of the Communist University of the Toiling People of the East, and Karl Radek, the main adviser of the Executive Committee of the Communist International [РГАСПИ. Ф. 17. Оп. 163. Д. 546. Л. 57].

The great Stalinist purges of 1937-1938 had an enormous influence on the encyclopaedia's content. In June 1937, editor-in-chief Otto Schmidt wrote a letter to the Political Bureau of the Communist Party where he 
mentioned the necessity of preparing the second edition of the GSE as soon as possible. Numerous biographical entries and associated entries on the social, political, military, and economic policy of the Soviet Union should be revised or rewritten. He also proposed providing the editorial board with exclusive censorship rights and even adopting a special binding that would allow for the easy replacement of ideologically incorrect pages [РГАСПИ. Ф. 82. Оп. 2. Д. 981. Л. 30]. Despite numerous difficulties, the first edition of the GSE was completed in 1947, with sixty-five volumes in print.

The experience and recommendations of the editing board of the first edition started a rethink on the publishing of the second edition. With the planned economy and agriculture under the leadership of the Communist Party, it was impossible to leave encyclopaedia publishing alone. The new edition of the GSE was to serve as the representative image of Soviet science and not as a private forum for contributors to express and distribute their thoughts and ideas according to their own free will. Therefore, the Soviet encyclopaedia had to change and become one more area under the control and regulations of the party. In February 1949, a decree of the Council of Ministers of the USSR regarding the new edition of the GSE was published in the newspaper Kul'tura i Zhizn' (Culture and Life). Culture and Life was a second-rank Soviet newspaper compared to Pravda (Truth) and Izvestiia (News), indicating that culture and science in the Soviet Union occupied a secondary place in the overall hierarchy of things. The decree stated that the Council of Ministers should organize encyclopaedia publishing according to the standards of the planned economy. The new edition of the GSE should become an organized set of materials on the social, economic, and natural sciences, technology, and other important fields of knowledge. The new edition must emphasize the historical achievements of socialist construction in the Soviet Union and become a universal guide for the Soviet intelligentsia in particular and every Soviet citizen in general [Вавилов, Зворыкин, с. 7-17; Введенский, Зворыкин, с. 3-18; О новом издании Большой Советской энциклопедии]. In the same decree, the first edition of the Soviet encyclopaedia was criticized for a lack of planning with regards to its entries' length and content, the absence of coordination between encyclopaedia departments and sub-departments, isolation, ignoring important events of Soviet reality (particularly, the Great October Socialist Revolution), exaggeration, and incorrect information on the historical role of certain political figures and their influence.

A notable feature of the second edition is the absence of publishing year within its volumes and the lack of a list of encyclopaedia departments and sub-departments. All of the invisible work was concealed from public view, so the published volumes showed only the tip of the iceberg. The list of the academic editorial board consisted of twenty-two members, who were recognized authorities in their fields of knowledge. This list, published in the first volume of the second edition, serves as an interesting case study of the priorities of Soviet science in the 1950s. It was the beginning of the Cold War and the long economic competition between the Soviet Union 
and the United States. Every field of knowledge and economic branch in the Soviet Union was given a strategic meaning and role in this exhausting race. Fourteen out of twenty-one members of the academic editorial board represented the natural and applied sciences, such as nuclear physics, radio engineering, chemistry, biochemistry, medicine, geology, machinery and technology, and astronomy.

The editorial board members representing the natural and applied sciences were well-balanced by seven members from the social and historical sciences; practically all of them held important party and administrative duties. The GSE State Publishing House established encyclopaedia publishing as a collaborative effort between central and republican academic institutions, professors and teaching staff in institutions of higher education, party bodies and activists, different ministries, and the staff of industrial and agricultural enterprises. Fedor Petrov (1876-1973) was one of the founding fathers of the GSE Publishing House and its actual director during the publication of the second edition; Petr Pospelov (1898-1979) was the editor-in-chief of Pravda, the main newspaper of the Soviet Union, editor and co-author of the Short Course of the History of the All-Union Communist (Bolshevik) Party, and the creator of Stalin's personality cult through his short biography. Sergei Vavilov (1891-1951), a famous physician and president of the Soviet Academy of Sciences, was appointed academic editor-in-chief of the second edition. After his death, the post was occupied by Boris Vvedenskii (1893-1969), director of Radio-Technic and the Electronics Institution of the Academy of Sciences.

Stalin's spirit was palpably present in every encyclopaedia entry. In the editorial preface to the first volume of the second edition, Stalin's Short Course was compared to an encyclopaedia of philosophical thought for its innovations in theoretical Marxism-Leninism [От редакции, б. г., с. 1]. It is impossible to find even one volume without pictures of Stalin or obligatory citations from his works.

The contributors to the second edition were obligated to cite MarxistLeninist classics on every subject, even those as distant from ideology as animal husbandry or urbanism [Животноводство, с. 118; Урбанизм, c. 312]. Konstantin Derzhavin (1903-1956), a literary critic and specialist on the literature of the Spanish Renaissance and French Enlightenment, was asked to enrich his entry with citations from Marxist classics on the literary and historical development of Spain, the influence of Russian revolutionary democrats on the Spanish revolutionary movement, the history of Spanish anarchism in the age of imperialism, and the history of RussianSpanish relations, none of which has much, or even any, connection to the entry's content [ОР РНБ. Личный фонд К. А. Державина. Ф. 1028. Д. 80. Л. 3-4; Испания, с. 560-561].

The editorial departments of the second edition were organized anew according to the field of knowledge. There were departments of archaeology and ethnography, biology, the military sciences, general history, geography and geology, art, the history of the USSR and the Communist Party, 
literature and linguistics, mathematics and astronomy, people's education and publishing, law, agriculture, technology, physics, sport and physical culture, philosophy, chemistry, and the economy. The GSE's second edition used a double system of censorship and professional validation. Several thematically close departments were organized into a 'subject area' with a subject editor at its head. Every single department had its own department editor, who was responsible for the work within his department. Every entry had to be approved by the subject editor and sent for a second opinion. The entry was then returned to the department editor in order to be referred to other department editors within the 'subject area' and, if necessary, with department editors of other 'subject areas'. After checking the relevant references, the entry passed to the information department, whose duty it was to verify entry dates and events according to the officially approved reference sources. The bibliography department had to verify the entry's bibliography according to citation rules. If the entry included maps, sketches, or illustrations, additional checking was obligatory in order to avoid gaps between the text and the visual material. Every cycle of verification had to be signed by the responsible editor or the encyclopaedia's editor-in-chief, who coordinated the work of all the academic and supporting departments. The editor responsible for the second edition was Anatolii Zavorykin (1901-1988), an economist and specialist in the history of technology.

Another task of the GSE's departments was the preparation of subject word-lists. Drafts of such lists were developed by the staff of the subject area departments and were later sent for review by other such departments in order to avoid repetitions. For example, the word-list of the biology subject area were sent to related departments (anthropology, archaeology and ethnography) [Методические указания, с. 25-33]. Subject word-lists were later published in a limited number of copies and sent to relevant academic institutions, universities, libraries, museums, and party and soviet organizations for further discussion and proposals. All proposals for changes within the word-list were to be sent in written form to the State Scientific Institute 'Soviet Encyclopaedia' [Словник по истории Ближнего и Среднего Востока, с. 1; Словник по истории религии, c. 3-4; Словник по языкознанию, с. 4-5]. A subject word-list defined the number of printed characters for each entry, as well as the bibliographical reference demands (detailed bibliography, main bibliography, limited bibliography, reference bibliography within the text) and the need for and quantity of additional entry elements (maps, tables, sketches, portraits). For each category of biographical entry, the portrait size was standardized [Словник по истории техники, с. 2; Словник по экономике, с. 3; Словники по географии, с. 2].

Readers of the GSE's second edition were also provided with a short guide on how to navigate between different entries and use them with maximum efficiency. Two systems of bibliographical notes were used for biographical and other entries. Every biographical entry provided a list 
of main personal works (Sochineniia), while other entries provided the reader with a subject bibliography (Literatura) in Russian and foreign languages. The second edition lacked updated foreign sources: only pre-revolutionary sources are found in the bibliographies. This can be explained by the need to demonstrate the advantages of Soviet science: bourgeois science was fallacious because of its social character, so the Soviet reader should see only the triumph of Soviet science and culture. Foreign names were accompanied by their original transliteration. Word etymology was provided only if it helped one obtain a better understanding of the entry's content. Historical dates were in a state of complete confusion: events from European history were provided according to the Gregorian calendar; events from Russian and Soviet history from the February Revolution until the transition to the new calendar at the beginning of 1918 were provided in both styles; pre-revolutionary Russian history was dated according to the old calendar; and events of Soviet history from 1918 were provided according to the new style. If necessary, international events would be given in both calendar styles [Указания авторам, с. 640].

The Twentieth Congress of the CPSU (14-26 February 1956), with Khrushchev's famous speech on the need to eradicate the Cult of Personality and return to the revolutionary transformation of society, had an immediate impact on the content of the second edition [Khrushchev, p. 117-134]. Numerous publications in leading academic journals, newspapers, and letters sent by encyclopaedia readers to the GSE editorial board called for the restoration of historical justice and objectivity and, if necessary, to revise and publish the encyclopaedia anew. The history of the Russian revolutionary movement, the Bolshevik revolution, the Communist Party of the Soviet Union, and the socialist reconstruction of the economy and agriculture were especially criticized [Максаков, с. 123-130; Денисов, с. 140-145].

As a result of this criticism, the encyclopaedia's editorial board decided to correct the ideological mistakes in biographical entries by replacing them with other entries. Encyclopaedia subscribers were provided with new entries and instructions on what entry should be replaced in which volume. Selected entries had to be carefully cut out and sent back to the GSE Publishing House. The most famous example of this 'cut and paste' system were the entries on 'the Bering Sea' and 'Bering Channel' in the fifth volume (1951). The 'Bering Channel' entry is four times longer than the 'Bering Sea' entry following it for a very simple reason: this entry replaced the original entry on 'Lavrentii Beria'. Beria (1899-1953), Stalin's righthand man, head of the People's Commissariat for Internal Affairs (NKVD), and first deputy prime minister, was arrested shortly after Stalin's death on 5 March 1953 and executed in December 1953. Subscribers were asked to cut out pages $21,22,23$, and 24, as well as Beria's portrait between pages 22 and 23 in volume five, and replace them with the 'Bering Channel' entry and a new picture list [Лаврентий Берия, с. 18-22].

In 1957, an additional fifty-first volume was published, which included revised encyclopaedia entries and numerous new reference and biographical 
entries recommended for publication by the editorial board. The templates for biographical entries were changed and included references to pre-revolutionary scientific activity and membership of/awards from foreign science or art academies [ОР РНБ. Личный фонд Г. С. Верейского. Ф. 1129. Д. 469. Л. 1].

The second edition of the GSE came to an end in 1957, containing forty-nine encyclopaedia volumes, one subject volume (volume fifty was devoted to the USSR and was especially published for the $40^{\text {th }}$ anniversary of the Great October Socialist Revolution), and one additional volume (volume fifty-one). It included about 5,000 printed sheets and more than 96,000 key terms. An extended bibliography was provided for 41 percent of the entries in 35 languages of the Soviet Union nationalities and 25 foreign languages, including Chinese and Japanese logographic writing. Numerous entries from the second edition were translated and published as selected entries in books and brochures outside the Soviet Union. The number of temporary encyclopaedia contributors stood at 9,400 persons; the general number of encyclopaedia contributors was as great as 15,820. Foreign contributors were also welcomed. Special bureaus and departments working jointly with the GSE Publishing House were organized in practically all the countries of the socialist camp: in Poland, a special commission on reviewing encyclopaedia entries was established; in China, a 'GSE working group' within the agitation and propaganda department of the Central Committee of the Chinese Communist Party was organized; and in the German Democratic Republic, encyclopaedia entries were written and reviewed by the Marxism-Leninism Institute in Berlin and the Leipzig Bibliographical Institute [От редакции, б. г., с. 3-4]. The second edition was printed in 300,000 copies, while the price of a single encyclopaedia volume was 55 rubles, making it readily available to individual subscribers. After the monetary reform of 1947 and the abolition of wartime rationing cards, the monthly salary of workers and state employers stood at about 640 rubles; by 1953, this grew to 800 rubles [Барсенков, Вдовин, с. 605-607]. The GSE Publishing House's subscriptions were underlined by a state order that guaranteed a certain number of copies and subscribers.

However, the GSE was far from being a repository of knowledge and the foundation for social progress. It became a monument of scientific stagnation and ideological dogmatism; despite efforts in the last years of its publication, the second edition of the GSE became known as a "Stalinist" encyclopaedia. Its navy blue covers on library shelves became a visible monument to this dark epoch in the history of the Soviet Union.

In 1957 the GSE Publishing House began releasing annual supplement volumes with updated information on important entries. In 1960, a twovolume alphabetical index to the second edition was published [Большая советская энциклопедия: алфавитный указатель]. In the introductory message from the editorial board for the 1957 annual supplement, the requirement to change and enrich some entries in accordance with the decisions of the February and June 1957 plenums of the Central Committee of the CPSU (which confirmed the need to overcome remnants 
of the personality cult and reaffirmed Khrushchev's position as first secretary) was mentioned. Revised entries became less politicized and more professional, while mandatory mention of Stalin's works disappeared [Германия, с. 275-287].

The establishment of encyclopaedia publishing in the Soviet Union can be characterized as one of the most politicized and institutionalized attempts to compile a system of final and absolute knowledge, a system of influence and power. The state had exclusive rights on encyclopaedia content, encyclopaedia distribution, and establishing the policy of ideological reading literacy. The first edition of the GSE served as an experimental basis for further editions. The relative freedom of the editorial board and contributors was replaced by strict regulations and instructions from above. Soviet encyclopaedias learned to use all paratext features in order to suggest to the reader a specific interpretation or understanding of the text. Soviet encyclopaedias were printed in huge numbers without any thought given to profits because distribution was guaranteed by the state.

\section{Список литературы}

«О новом издании Большой Советской энциклопедии» : постановление Совета министров СССР // Культура и жизнь. 1949. 20 февр. С. 1.

Барсенков А. С., Вдовин А. И. История России, 1917-2009 : учеб. пособие для студентов высш. учеб. заведений. М. : Аспект Пресс, 2010. 845 с.

БСЭ : алфавитный указатель ко 2-му изд. : в 2 т. М. : БСЭ, $1960.800+775$ с.

Вавилов С. И., Зворыкин А. А. Второе издание Большой Советской энциклопедии // Советская книга. 1951. № . 7. С. 7-17.

Введенский Б. А., Зворыкин А. А. Десять томов нового издания Большой Советской энциклопедии // Советская книга. 1952. № 8. С. 3-18.

Вольфсон М. Б. Пути советской книги. М. : Госиздат, 1929. 112 с.

Германия. Германская Демократическая Республика. Федеративная Республика Германия // БСЭ : ежегодник. М. : БСЭ, 1957. С. 275-287.

Декреты Советской власти : в 12 т. М. : Политиздат, 1986. Т. 12. Декабрь 1920 г. январь 1921 г. 428 с.

Денисов Г. М. Об освещении в Большой Советской энциклопедии деятельности выдающихся большевиков // Вопр. истории. 1956. № 5. С. 140-145.

Животноводство // БСЭ. 2-е изд. М. : БСЭ, [Б. г.]. Т. 16. С. 118.

Зайдель Г. С. Большая Советская энциклопедия, тт. I-VIII : Статьи по всеобщей истории // Историк-марксист. 1928. № 7. С. 239-244.

Испания // БСЭ. 2-е изд. М. : БСЭ, [Б. г.]. Т. 18. С. 530-591.

Лаврентий Берия // БСЭ. 2-е изд. М. : БСЭ, [Б. г.]. Т. 5. С. 18-22.

Максаков В. В. Вопросы истории Первой русской революции в Большой Советской энциклопедии (1-27 тт., 2-е изд.) // Вопр. истории. 1955. № 2. С. 123-130.

Методические указания для редакторов Большой Советской энциклопедии. 3-е изд. БСЭ / под общ. ред. Л. С. Шаумяна ; [сост. С. Р. Гершберг, М. Э. Струве, Ю. Е. Шмушкис]. М. : Сов. энцикл., 1969. 302 с.

ОР РНБ. Ф. 221 (Архив А. Горенфельда). Д. 358; Ф. 1028 (Личный фонд К. А. Державина). Д. 804; Ф. 1129 (Личный фонд Г. С. Верейского). Д. 469.

Осинский Н. Дела и дни Большой Советской энциклопедии // Правда. 1929. 15 марта. С. 1.

От редакции // БСЭ. 1-е изд. М. : Сов. энцикл., 1926. Т. 1. С. 1-2.

От редакции // БСЭ. 2-е изд. М. : БСЭ, [Б. г.]. Т. 1. С. 1. 
РГАСПИ. Ф. 17. Оп. 163. Д. 546; Ф. 82. Оп. 2. Д. 981.

Редакторы отделов и подотделов // БСЭ. 1-е изд. М. : Сов. энцикл., 1926. Т. 1. С. 3.

Симзен М. Ю. Из истории национализации полиграфической промышленности в СССР // Вопр. истории. 1963. № 3. С. 211-214.

Словник по всеобщей истории // Проект словников второго издания БСЭ : рукопись для обсуждения в гл. ред. БСЭ : в 12 т. М. : БСЭ, 1949-1951. Ч. 1. История древнего мира. 20 с. Ч. 2. История Средних веков. 51 с. Ч. 3. Новая и новейшая история. 94 с. Ч. 4. История стран зарубежного Востока. 31 с.

Словник по истории Ближнего и Среднего Востока // Проект словников второго издания БСЭ : рукопись для обсуждения в гл. ред. БСЭ : в 12 т. М. : БСЭ, 1949-1951. 35 с.

Словник по истории религии и атеизма // Проект словников второго издания БСЭ : Рукопись для обсуждения в гл. ред. БСЭ : в 12 т. М. : БСЭ, 1949-1951. 28 с.

Словник по истории техники // Проект словников второго издания БСЭ : Рукопись для обсуждения в гл. ред. БСЭ : в 12 т. М. : БСЭ, 1949-1951. 6 с.

Словник по экономике // Проект словников второго издания БСЭ : Рукопись для обсуждения в гл. ред. БСЭ : в 12 т. М. : БСЭ, 1949-1951. 35 с.

Словник по языкознанию // Проект словников второго издания БСЭ : Рукопись для обсуждения в гл. ред. БСЭ : в 12 т. М. : БСЭ, 1949-1951. 22 с.

Словники по географии // Проект словников второго издания БСЭ : рукопись для обсуждения в гл. ред. БСЭ : в 12 т. М. : БСЭ, 1949-1951. Ч. 2. Экономическая география СССР. 35 с.

Указания авторам // БСЭ. 2-е изд. М. : БСЭ, [Б. г.]. Т. 1. С. 640.

Урбанизм // БСЭ. 2-е изд. М. : БСЭ, [Б. г.]. Т. 44. С. 312.

Энциклопедии советские // БСЭ. 1-е изд. М. : Сов. энцикл., 1926. Т. 64. С. 498-502.

Kassof B. A Book of Socialism: Stalinist Culture and the First Edition of the Bol'shaia sovetskaia entsiklopediia // Kritika: Explorations in Russian and Eurasian History. Vol. 6. No. 1. Winter 2005. P. 55-95.

Khrushchov N. S. 1956 Report of the Central Committee of the Communist Party of the Soviet Union to the $20^{\text {th }}$ Party Congress. Moscow : Foreign Languages Publ. House, 1956. $144 \mathrm{p}$.

Steila D. A Proletarian Encyclopédie // Word and Image in Russian History: Essays in Honor of Gary Marker / ed. by M. Salvo, D. Kaiser, V. Kivelson. Brighton, MA : Acad. Studies Press, 2015. P. 90-117.

\section{References}

Barsenkov, A. S., Vdovin, A. I. (2010). Istoriya Rossii, 1917-2009. Uchebnoe posobie dlya studentov vysshikh uchebnykh zavedenii [History of Russia: 1917-2009. A Tutorial for University Students]. Moscow, Aspekt Press. 845 p.

BSE : Alfavitnyi ukazatel'ko vtoromu izdaniyu v $2 t$. [The Great Soviet Encyclopaedia. Alphabetical Index to the Second Edition. 2 Vols.]. (1960). Moscow, BSE. $800+775$ p.

Dekrety Sovetskoi vlasti v 12 t. [Decrees of Soviet Power. 12 Vols.]. (1986). Moscow, Politizdat. Vol. 12. Dekabr' 1920 g. - yanvar' 1921 g. 428 p.

Denisov, G. M. (1956). Ob osveshchenii v Bol'shoi Sovetskoi Entsiklopedii deyatel'nosti vydayushchihsya bol'shevikov [On the Reflection of Outstanding Bolsheviks' Activity in the Great Soviet Encyclopaedia]. In Voprosy istorii. No 5, pp. 140-145.

Entsiklopedii sovetskie [Soviet Encyclopaedias]. (1926). In BSE. $1^{\text {st }}$ Ed. Moscow, Sovetskaya entsiklopediya, pp. 498-502.

Germaniya. Germanskaya Demokraticheskaya Respublika. Federativnaya Respublika Germaniya [Germany. German Democratic Republic. Federative Republic of Germany]. (1957). In BSE : ezhegodnik. Moscow, BSE, pp. 275-287.

Ispaniya [Spain]. (N. d.). In BSE. $2^{\text {nd }}$ Ed. Moscow, BSE. Vol. 18, pp. 530-591.

Kassof, B. (2005). A Book of Socialism. Stalinist Culture and the First Edition of the Bol'shaia Sovetskaia Entsiklopediia. In Kritika: Explorations in Russian and Eurasian History. Vol. 6. No. 1. Winter, pp. 55-95. 
Khrushchev, N. S. (1956). 1956 Report of the Central Committee of the Communist Party of the Soviet Union to the $20^{\text {th }}$ Party Congress. Moscow, Foreign Languages Publ. House. 144 p.

Lavrentiy Beria [Lavrentiy Beria]. (N. d.). In BSE. $2^{\text {nd }}$ Ed. Moscow, BSE. Vol. 5, pp. 18-22.

Maksakov, V. V. (1955). Voprosy istorii Pervoi Russkoi revolutsii v Bol'shoi Sovetskoi entsiklopedii (1-27 tt., 2-e izd.) [Questions on the History of the First Russian Revolution in the Great Soviet Encyclopaedia (Vols. 1-27, $2^{\text {nd }}$ Edition)]. In Voprosy istorii. No. 2, pp. $123-130$.

"O novom izdanii Bol'shoi Sovetskoi Entsiklopedii" : postanovlenie Soveta Ministrov SSSR ["On the New Publication of the Great Soviet Encyclopaedia": Decree of the Council of Ministers of the USSR]. (1949). In Kul'tura i zhizn'. February 20, p. 1.

OR RNB [Manuscript Department, National Library of Russia]. Stock 221 (Arkhiv A. Gorenfel'da). Dos. 358; Stock 1028 (Lichnyi fond K. A. Derzhavina). Dos. 804; Stock 1129 (Lichnyi fond G. S. Vereiskogo). Dos. 469.

Osinskii, N. (1929). Dela i dni Bol'shoi Sovetskoi entsiklopedii [Deeds and Days of the Great Soviet Encyclopaedia]. In Pravda. March 15, p. 1.

Ot redaktsii [From the Editors]. (1926). In BSE. $1^{\text {st }}$ Ed. Moscow, Sovetskaya entsiklopediya. Vol. 1, pp. 1-2.

Ot redaktsii [From the Editors]. (N. d.). In BSE. $2^{\text {nd }}$ Ed. Moscow, BSE. Vol. 1, p. 1.

Redaktory otdelov i podotdelov [Departments and Sub-Department Editors]. (1926). In $B S E .1^{\text {st }}$ Ed. Moscow, Sovetskaya entsiklopediya. Vol. 1, p. 3.

$R G A S P I$ [Russian State Archive of Social-Political History]. Stock 17. List 163. Dos. 546; Stock 82. List 2. Dos. 981.

Shaumyan, L. S. (Ed.). (1969). Metodicheskie ukazaniya dlya redaktorov Bol'shoi Sovetskoi entsiklopedii. 3-e izd. BSE [Guidelines for the Editors of the Great Soviet Encyclopaedia. 3 Ed.]. Moscow, Sovetskaya entsiklopediya. 302 p.

Simzen, M. Yu. (1963). Iz istorii natsionalizatsii poligraficheskoi promyshlennosti $\mathrm{v}$ SSSR. [On the History of the Nationalisation of the Printing Industry in the USSR]. In Voprosy istorii. No. 3, pp. 211-214.

Slovnik po ekonomike / Proekt slovnikov vtorogo izdaniya BSE : rukopis' dlya obsuzhdeniya $v$ glavnoi redaktsii BSE v $12 t$. [Word-List on Economics. Word-List Draft of the $2^{\text {nd }}$ Edition of the Great Soviet Encyclopaedia. A Manuscript for Discussion at the Editorial Board Meeting of the Great Soviet Encyclopaedia. 12 Vols.]. (1949-1951). Moscow, BSE. $35 \mathrm{p}$.

Slovnik po istorii Blizhnego i Srednego Vostoka / Proekt slovnikov vtorogo izdaniya $B S E$ : rukopis' dlya obsuzhdeniya v glavnoi redaktsii BSE v $12 t$. (Word-List on the History of the Near and Middle East. Word-List Draft of the $2^{\text {nd }}$ Edition of the Great Soviet Encyclopaedia. A Manuscript for Discussion at the Central Publishing of the Big Soviet Encyclopaedia. 12 Vols.]. (1949-1951). Moscow, BSE. 35 p.

Slovnik po istorii religii i ateizma / Proekt slovnikov vtorogo izdaniya BSE : rukopis' dlya obsuzhdeniya v glavnoi redaktsii BSE v $12 \mathrm{t}$. [Word-List on the History of Religion and Atheism. Word-List Draft of the $2^{\text {nd }}$ Edition of the Great Soviet Encyclopaedia. A Manuscript for Discussion at the Editorial Board Meeting of the Great Soviet Encyclopaedia. 12 Vols.]. (1949-1951). Moscow, BSE. 28 p.

Slovnik po istorii tekhniki / Proekt slovnikov vtorogo izdaniya BSE : rukopis' dlya obsuzhdeniya $v$ glavnoi redaktsii BSE v $12 \mathrm{t}$. [Word-List on the History of Technology. Word-List Draft of the $2^{\text {nd }}$ Edition of the Great Soviet Encyclopaedia. A Manuscript for Discussion at the Editorial Board Meeting of the Great Soviet Encyclopaedia. 12 Vols.]. (1949-1951). Moscow, BSE. 6 p.

Slovnik po vseobshchei istorii / Proekt slovnikov vtorogo izdaniya BSE : rukopis'dlya obsuzhdeniya v glavnoi redaktsii BSE v 12 t. [Word-List on General History. Word-List Draft of the $2^{\text {nd }}$ Edition of the Great Soviet Encyclopaedia. A Manuscript for Discussion at the Editorial Board Meeting of the Great Soviet Encyclopaedia. 12 Vols.]. (19491951). Moscow, BSE. Part 1. Istoriya Drevnego mira. 20 p. Part 2. Istoriya Srednikh 
vekov. 51 p. Part 3. Novaiya i noveishaiya istoriya. 94 p. Part 4. Istoriya stran zarubezhnogo Vostoka. 31 p.

Slovnik po yazykoznaniyu / Proekt slovnikov vtorogo izdaniya BSE : rukopis'dlya obsuzhdeniya v glavnoi redaktsii BSE v $12 \mathrm{t}$. [Word-List on Linguistics. Word-List Draft of the $2^{\text {nd }}$ Edition of the Great Soviet Encyclopaedia. A Manuscript for Discussion at the Central Publishing of the Great Soviet Encyclopaedia. 12 Vols.]. (1949-1951). Moscow, BSE. 22 p.

Slovniki po geografii / Proekt slovnikov vtorogo izdaniya BSE : rukopis' dlya obsuzhdeniya v glavnoi redaktsii BSE v $12 t$. [Word-List on Geography. Word-List Draft of the $2^{\text {nd }}$ Edition of the Great Soviet Encyclopaedia. A Manuscript for Discussion at the Editorial Board Meeting of the Great Soviet Encyclopaedia. 12 Vols.]. (1949-1951). Moscow, BSE. Part 2. Ekonomicheskaya geografiya SSSR. 35 p.

Steila, D. (2015). A Proletarian Encyclopédie. In Salvo, M., Kaiser, D., Kivelson, V. (Eds.). Word and Image in Russian History: Essays in Honor of Gary Marker. Brighton, MA, Acad. Studies Press, pp. 90-117.

Ukazaniya avtoram [Instructions for Authors]. (N. d.). In BSE. $2^{\text {nd }}$ Ed. Moscow, BSE. Vol. 1, p. 640.

Urbanizm [Urbanism]. (N. d.). In BSE. $2^{\text {nd }}$ Ed. Moscow, BSE. Vol. 44, p. 312.

Vavilov, S. I, Zvorykin, A. A. (1951). Vtoroe izdanie Bol'shoi Sovetskoi Entsiklopedii [The Second Edition of the Great Soviet Encyclopaedia]. In Sovetskaya kniga. No. 7, pp. 7-17.

Vol'fson, M. B. (1929). Puti sovetskoi knigi [Ways of the Soviet Book]. Moscow, Gosizdat. $112 \mathrm{p}$.

Vvedenskii, B. A., Zvorykin, A. A. (1952). Desyat' tomov novogo izdaniya Bol'shoi Sovetskoi Entsiklopedii [Ten Volumes of the New Edition of the Great Soviet Encyclopaedia]. In Sovetskaya kniga. No. 8, pp. 3-18.

Zaidel', G. S. (1928). Bol'shaya Sovetskaya entsiklopediya, tt. I-VIII. Stat'i po vseobshchei istorii [The Great Soviet Encyclopaedia, Vol. 1-8. Entries on General History]. In Istorik-marksist. No. 7, pp. 239-244. p. 118.

Zhivotnovodstvo [Animal Husbandry]. (N. d.). In BSE. $2^{\text {nd }}$ Ed. Moscow, BSE. Vol. 16,

The article was submitted on 10.05.2018 